\title{
KONSTRIBUSI DAN IMPLIKASI PENGEMBANGAN PENDIDIKAN TINGGI PADA PONDOK PESANTREN MENGHADAPI PERSAINGAN GLOBAL
}

\section{S. Ali Jadid Al Idrus*}

\begin{abstract}
Abstrak: Pondok pesantren sebagai lembaga pendidikan, dakwah dan lembaga sosial harus tetap mempertahankan ideologi, idintitas serta paradigma pendidikannya, juga beradaptasi serta relevan dengan perkembangan global, yakni menerima perkembangan ilmu pengetahuan serta menjadi lembaga yang dibutuhkan masyarakat dalam memecahkan permasalahan ummat. Pendidikan tinggi pesantren tidak saja sebagai organisasi sosial, namun juga organisasi dakwah, pengembang sumber daya manusia serta pusat pengembangan ilmu pengetahuan berbasis Islam dan global. secara fungsional memiliki berbagai peran memberikan pelayanan pendidikan dan pengajaran, juga sebagai agen perubahan atau pembaharuan dalam masyarakat. Sistem yang terbuka terhadap lingkungannya dan terintegral dari sistem sosial yang lebih besar, yakni masyarakat. Pengaruh masyarakat terhadap pesantren sangat kuat, demikian pula pengaruh pesantren terhadap masyarakat, kepada individu-individu yang ada dalam lingkungan karena keberadaan pesantren berada ditengah-tengah kehidupan dan menjadi bagian dari masyarakat. Secara operasional, kerjasama yang dilakukan pesantren dibina dengan baik untuk mendapatkan simpati dari masyarakat, pesantren terus melakukan inovasi, dengan meningkatkan layanan kepada masyarakat dengan cara menampilkan produk-produk unggulan yang dapat memenuhi kebutuhan masyarakat itu sendiri.
\end{abstract}

Kata Kunci: konstribusi, implikasi, pengembangan, pendidikan tinggi, ponpes, globalisasi.

Jurusan Pendidikan Bahasa Arab. Email: s.alijadid75@gmail.com 
P ondok pesantren dituntut untuk mengadakan usaha kontekstualisasi konstruktif sistem dan orientasi kependidikannya seperti aspek-aspek administrasi, diferensiasi struktural, ekspansi kapasitas, dan transformasi out put pesantren (Mastuhu, 1994:154). Pendidikan pondok peantren yang dikembangkan memiliki orientasi pada: (1) pendidikan bukanlah upaya mewariskan paham/pola keagamaan tertentu, (2) ditekankan pada proses memperoleh kemampuan metodologis dalam memahami kesan dan pesan yang diberikan agama, (3) tidak terpaku pada romantisme berlebihan namun diarahkan kepada pembentukan berpikir obyektif dalam menyikapi tantangan kehidupan, (4), materi pengajaran diintegrasikan dengan menumbuh kembangkan sikap kepedulian sosial, (5) dikembangkan wawasan emansipatoris, dan kemampuan metodologis dalam mempelajari substansi atau materi agama, (6) pendidikan diarahkan untuk menanamkan keharuan emosional keagamaan (akblakul karimah) (Muslim Abdurrahman, 1985:10).

Secara fungsional semua komponen yang ada di pesantren ikut bertanggung jawab pada proses hubungan dengan masyarakat, namun dalam pelaksanaannya setiap komponen harus berperan sesuai dengan fungsi masing-masing. Kerja sama dibutuhkan juga dengan lembaga-lembaga riset yang ada di dalam dunia industri dan masyarakat, dengan demikian adanya kerja sama yang saling menguntungkan baik untuk pendidikan tinggi sendiri maupun untuk industri. Semangat pengembangan pendidikan yang global dengan mengandung nilai ilahiyah dan insaniyah, sebagaimana dapat dilihat dari kandungan ayat al Qur'an surat Ali Imran ayat 190-191:

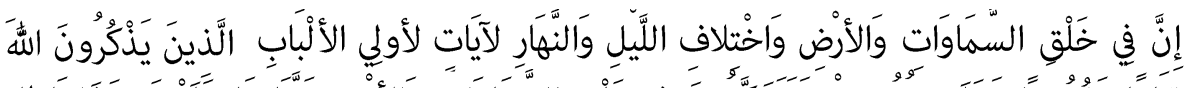

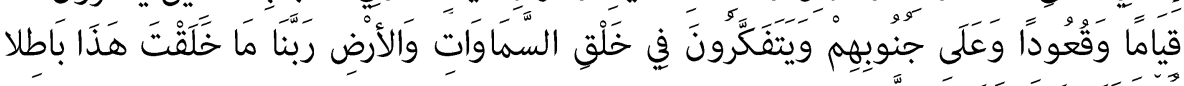

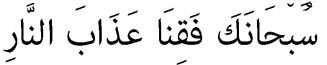

Artinya: Sesungguhnya dalam penciptaan langit dan bumi, dan silih bergantinya malam dan siang terdapat tanda-tanda bagi orang-orang yang berakal, (yaitu) orang-orang yang mengingat Allah sambil berdiri atau duduk atau dalam keadaan berbaring dan mereka memikirkan tentang 
penciptaan langit dan bumi (seraya berkata): "Ya Tuhan kami, tiadalah Engkau menciptakan ini dengan sia-sia. Maha Suci Engkau, maka peliharalah kami dari siksa neraka.

Pesantren dan lembaga-lembaga pendidikan khususnya lembaga pendidikan tinggi merupakan institusi (lembaga) yang memberikan pelayanan jasa pendidikan terhadap masyarakat yang memiliki karakteristik khusus, yaitu keislaman. Pelayanan jasa pendidikan ini membutuhkan interaksi keterlibatan masyarakat karena sangat menentukan perkembangan dan desain program pesantren. Pada dasarnya, untuk keberlangsungan pesantren, dalam memberikan pelayanan pendidikan, tidak akan terlepas dari lingkungan dimana pendidikan tinggi tersebut berada. Berikut gambaran tentang dampak pengembangan pendidikan tinggi di pondok pesantren.

\section{Tinjaun Teori dan Strategi Pengembangan}

\section{Revitalisasi dan rekonstruksi budaya}

Pendidik dan pengajar; penentu arah isi pendisikan, transfer pengetahuan dan keterampilan. Tokoh-tokoh Rekonsrtusianisme seperti George S. Counts, melihat masyarakat yang berada dalam krisis, tulisan yang mula-mula disusun oleh Counts tentang pendidikan, menunjukan adanya tantangan terhadap pendidikan sebagai institusi untuk membentuk masyarakat baru dengan tantangan baru. Rekonsrtusianisme menghendaki pendidikan sebagai wahan untuk mengadakan perubahan. perubahan itu diperlukan agar dapat diciptakan kehidupan yang lebih baik. Mortimer J. Adler (1982), seorang eksponen neo-rasionalis dari perenialisme, mengatakan bahwa hendaklah pertama-tama mempersipakan kesuksesan, selanjutnya perguruan tinggi belajar secara konprehensip menurut pendidikan umum, akademik dan profesional. Dengan persiapan akan tahan menghadapi situasi pendidikan manapun, setiap waktu perlu mengarahklan subjek. Maka perlu memiliki keterampilan yang memadai, menunjuk perlunya latihan tertentu yang disebut coaching (Adler, 1982:60-61). Adapun rekonsrtusianisme memahami proses pendidik dan pengajar; dari pentansfer pengetahuan dan keterampilan menjadi 
el-HiKMAH, Vol. 10, No. 2, Desember 2016

transformator pengetahuan dan keterampilan. Teori Rekonsrtusianisme menempatkan mutu pada tempatnya yang utama.

Teori pengembangan Goldstein, Tannenbaun, Yurk dan Teori tindakan social Dirkhem dan pandamgan social Max Weber

Teori Developing menyatakan bahwa dalam mengembangkan perlu dilakukan latihan (Coaching), membimbing (Mentoring), serta konsultasi karir, yang digunakan untuk meningkatkan keterampilan dan memudahkan penyesuaian terhadap aktivitas serta terhadap kemajuan organisasi. Teori ini menyatakan bahwa pengembangan keterampilan dapat meningkatkan kepuasan dan kinerja para anggota organisasi dan mentoring berhubungan dengan komitmen dan kinerja para bawahan yang lebih tinggi (Garry Yulk, 1994: 104).

Dalam teori tindakan sosial Max Weber membagi menjadi empat tindakan dasar, salah satunya adalah teori tindakan tradisionl. Tindakan tradisional, yaitu perilaku yang tidak berdasarkan pemikiran, melainkan hanya tradisi dan kebiasaan (Haryanto, 2011:33). Aturan - aturan yang disepakati masyarakat dalam sistem, merupakan tradisi dan kebiasaan masyarakat yang berlaku secara turun- temurun. Kondisi ini berlangsung secara kontinyu tanpa adanya suatu perubahan kearah yang lebih modern, dan akadnya hanya dilakukan secara lisan, tanpa adanya perjanjian secara tertulis antar kedua belah pihak.

Sama dengan Max Weber, Durkheim mempertahankan suatu pandangan sosial yang radikal. Kesetiakawanan yang menunjuk pada satu keadaan hubungan antara individu dan atau kelompok yang didasarkan pada perasaan moral dan kepercayaan yang dianut bersama yang diperkuat oleh pengalaman emosional bersama". Solidaritas yang muncul pada masyarakat yang masih dan diikat oleh kesadaran kolektif, serta belum mengenal adanya pembagian kerja diantara para anggota kelompok disebut Solidaritas Mekanik (Haryanto, 2011:37). Sistem dalam masyarakat berlaku kuat dan perilaku masyarakatnya permanent dan menjadi budaya (kultur). 
Learning organization theory

Learning organization theory menunjukkan bahwa strategi merupakan pengetahuan kolektif karena pengalaman. Ada dua cara belajar organisasi yaitu: (1) simpul tunggal dan (2) simpul ganda. Cara belajar simpul tunggal adalah mendeteksi kesalahan dan membuat organisasi tetap berada dijalur tersebut. Sebaliknya, cara belajar simpul ganda adalah mempertanyakan apakah strategi benar dan memungkinkan eksekutif untuk mencerminkan secara kritis mengenai apa yang mereka lakukan dan mengajarkan kepada mereka untuk saling belajar dari sesama. Pemikiran Argyris tentang learning organization dikembangkan oleh Arie De Geus. De Geus berpendapat bahwa korporasi benar-benar hidup. Organisasi bukan hanya mesin pencetak uang namun harus memiliki identitas, tujuan dan arah diri.

De Geus menjelaskan bahwa fokus manajer dalam organisasi harus memperhatikan efesiensi produksi dan tidak melupakan sifat organisasi sebagai sifat komunitas manusia. Organisasi seharusnya tidak hanya belajar, namun organisasi perlu menetapkan prioritas sendiri dan mengabdikan diri sendiri. karena itu usaha organisasi untuk bertahan hidup dan memperbaikinya. Karakteristik organisasi adalah kemampuan untuk belajar, bersikap toleran, melakukan difusi kekuatan, dan saling percaya diantara organisasiorganisasi.

Pemikiran De Geus tentang learning organization dilengkapi lagi dengan pemikiran Peter M. Senge. Senge berpendapat bahwa organisasi perlu belajar secara kolektif dan membentuk visi kolektif yang bertanggung jawab. Untuk menjadi organisasi pembelajaran diperlukan lima disiplin (the fifth discipline), yaitu: (1) penguasaan pribadi, (2) model mental, (3) membangun visi bersama, (4) belajar dalam tim dan (5) pemikiran sitem. Pemikiran sistem adalah disiplin kelima yang memadukan semua disiplin dan melebur menjadi badan teori dan praktik yang saling melekat.

Konsep learning organization terus diperbaiki menjadi konsep Knowledge Management Structure (KMS) yang dikemukakan oleh Tom Peters "korporasi baru" harus menghancurkan birokrasi tetapi 
perlu memelihara pengetahuan, keterampilan, membina keahlian melalui peningkatan kekuatan unit skala pasar (market scale unit) dan yang mendorong unit tersebut untuk memberikan kontribusi pengetahuan untuk kemajuan korporasi (Kodrat, 2009: 16-18).

\section{Teori Brian Quinn}

Teori Brian Quinn menunjukkan bahwa strategi yang sebenarnya cenderung mengalami evolusi ketika keputusan internal dan pristiwa eksternal mengalir bersama untuk menciptakan consensus baru. Consensus baru ini akan mendapat dukungan luas. Teori Quinn adalah jenis perencanaan strategis dari atas ke bawah namun dilakukan dengan cara yang fleksibel dan proses belajar. Artinya karyawan diarahkan bekerja kearah tujuan yang ingin dicapai namum belum merubah target (proses formulasi strategi menyatu dengan implementasi). Proses ini lebih dikenal dengan "startegi sambil jalan". Pemimpin tidak menentukan, tetapi menjadi sponsor dan katalisator proses belajar organisasi. Pada saat startegi mulai mengkristal, tahapan-tahapan strategi sudah terimplementasikan. Melalui proses formulasi strategi, momentum dan komitmen psikologis terhadap strategi dibangun. Kelemahan teori Quinn adalah: (1) coba-coba memerlukan terlalu banyak waktu dan usaha, (2) sumber daya tidak digunakan secara terfokus, dan (3) metode ini tidak memadai dalam keadaan darurat (Kodrat, 2009: 16).

\section{Chaos Theory dan Complexity Theory}

Chaos Theory menunjukkan sebagian besar fenomena di dunia tidak mempunyai hubungan linier antara penyebab dengan akibat. Kekacauan menimbulkan pola non linier yang menetap. Salah satu ide yang paling penting dari kekacauan adalah ketergantungan sensitive pada kondisi awal. Ketergantungan pada kondisi awal mengatakan bahwa pengaruh yanga amat kecil dan sering tidak terdeteksi dapat mempunyai pengaruh yang besar. Oleh karena itu, harapkan hal-hal yang tidak diharapkan. Masukkan fleksibelitas dalam rencana. Kalau ada sesuatu yang salah, jangan mencari 
pelaku kesalahan untuk dihukum. Kalau ada yang benar, jangan berpikir itu karena Anda genius.

Dalam kekacauan, peluang juga penting. Peluang membawa first mover advantage (keuntungan yang bergerak pertama). Sistem yang paling kompleks amat sensitive pada kondisi awal sehingga berada dikedudukan yang paling menguntungkan dari perkembangan baru. Ide kunci yang lain dari kekacauan adalah kesamaan fractal. Bisnis juga fractal yaitu penuh dengan pola yang terjadi berulang-ulang yang hanya dikenali oleh mereka yang berpengalaman dalam pengamatan secara tepat jenis bisnis itu. Hal ini menjelaskan mengapa pengalaman dan intuisi lebih baik dari analisis dan kecerdasan baku. Bisnis fractal juga menjelaskan mengapa pasar yang tampaknya serupa memiliki faktor kunci sukses yang berbeda. Pedoman yang dapat dipakai disatu area mungkin tidak berhasil di pasar lain bahkan walaupun perbedaannya hanya sedikit (Kodrat, 2009: 18).

Complexity theory merupakan perkembangan dari chaos theory. Penambahan penting complexity theory atas chaos theory adalah: (1) kerumitan terjadi pada sistem umpan balik yang rumit, artinya dalam sistem ini sering terjadi hal-hal yang diluar dugaan, (2) kerumitan terkait dengan bagaimana setiap bagian memunculkan perilaku yang berbeda dari penjumlahan setiap bagian, misalnya: pelanggan individual muncul sebagai suatu pasar dan, (3) kerumitan lebih mungkin terjadi dalam sistem yang dimulai dari keadaan tidak teratur menjadi pola berskala besar dan dapat dikenali (Kodrat, 2009: 22).

\section{Pembahasan}

Partisipasi masyarakat yang efektif

Partisipasi yang efektif sebagai dampak dari pengembangan strategi dapat dipraktekkan masyarakat dalam bentuk keikutsertaan atau keterlibatan masyarakat dalam pengembangan pendidikan tinggi di pondok pesantren. Pengembangan yang berjalan dengan baik secara umum dapat berdampak pada tingkat partisipasi masyarakat sebagai akibat dari efektifnya strategi 
sehingga penerapan dilakukan oleh masyarakat dengan kebanggaan dan keikhlasan, akan tetapi munculnya partisipasi dalam bentukbentuk yang berbeda. Sebagai bagian dari dampak strategi pengembangan yang dilakukan pesantren dalam suatu interaksi sosial keterlibatan berbagai pihak dalam proses pengambilan keputusan atau pelaksanaan program merupakan suatu yang rutin dilakukan pesantren. dikarenakan melalui partisipasi inilah, keterlibatan terwujud dan keberlangsungan program akan relatif terjamin. Keterlibatan masyarakat dapat menumbuhkan keyakinan kolektif sebagai suatu yang dapat mendorong (self-fulling propechy) keberhasilan program.

Keragaman bentuk partispasi masyarakat secara fisik maupun non fisik menunjukkan bahwa perhatian mereka terhadap perkembangan pesantren sangat tinggi, demikian pula pemerintah telah menunjukkan partisipasi yang sangat tinggi terhadap perkembangan pembangunan pesantren khususnya dalam pengembangan pendidikan tinggi, ini dibuktikan dengan bertambahnya jenis dan jenjang pendidikan tinggi yang ada di pesantren, disamping itu pemerintah memberikan bantuan akademik dan non akademik kepada pesantren.

Partisipasi masyarakat tidak hanya sebatas pada bidang akademik saja, namun sudah dikembangkan beberapa bentuk partisipasi yang dapat mendukung proses pendidikan seperti biang sosial dan keagamaan. partisipasi masyarakat tidak terbatas pada bidang akademik, sarana dan prasarana. namun juga terlibat prosesproses pengembangan sehingga apa yang menjadi harapan bersama dapat tercapai, sementara pada bidang pendidikan berkisar pada bidang-bidang pendidikan diantaranya partisipasi masyarakat yang menguliahkan putra dan putrinya terlibat dalam pengembangan pendidikan, masyarakat membantu memperbaiki program pendidikan misalnya merumuskan kebijakan dan tujuan pendidikan, sebagai nara sumber, mengembangkan kurikulum yang lebih relevan dan sebagainya.

Partisipasi masyarakat terhadap pengembangan pendidikan dapat bertujuan untuk menyalurkan aspirasi dan prakarsa 
masyarakat dalam melahirkan kebijakan operasional dan program pendidikan di satuan pendidikan yang dikembangkan pondok pesantren, meningkatkan tangungjawab dan peranserta masyarakat dalam penyelenggaraan pendidikan, menciptakan suasana dan kondisi transparan, akuntabel dan demokratis dalam penyelenggaraan dan pelayanan pendidikan yang bermutu disatuan pendidikan yang dikembangkan pondok pesantren serta meningkatkan keterlibatan dan rasa memiliki masyarakat terhadap lembaga pendidikan yang dikembangkan pondok pesantren serta keterlibatan dalam mensosialisasikan lembaga pendidikan yang dikembangkan pondok pesantren kepada masyarakat yang lain.

\section{Lulusan yang bermutu dan berdaya saing}

Menghadapi era globalisasi dan informasi pondok pesantren perlu meningkatkan peranannya karena Islam yang dibawa oleh nabi Muhammad SAW sebagai agama yang berlaku seantero dunia sepanjang masa. Ini berarti ajaran Islam adalah global dan melakukan globalisasi untuk semua. Setiap persaingan yang keluar sebagai pemenang adalah yang berkualitas, yaitu memiliki iman dan taqwa, kemampuan, ilmu pengetahuan, teknologi dan keterampilan.

Argumen panjang lebar tak perlu dikemukakan lagi bahwa pada kenyataannya masyarakat muslim tidak bisa menghindarkan diri dari proses globalisasi komunikasi dan informasi dan jika pesantren yang mengelola perguruan tinggi ingin survive dan berjaya di tengah perkembangan dunia yang kian kompetitif di masa kini dan abad 21. para santri diharapkan memainkan peran dan fungsi ulama dan pengakuan terhadap keulamaan mereka biasanya pelan-pelan tapi pasti akan datang dari masyarakat, selain itu pesantren juga bertujuan menciptakan manusia muslim yang mandiri. Sebagai lembaga pendidikan Islam sepanjang sejarahnya pesantren berperan besar dalam rangka mencerdaskan dan meningkatkan martabat ummat muslimin. Tugas pokok yang dipikul pesantren selama ini, pada esensinya adalah mewujudkan manusia dan masyarakat muslim Indonesia yang beriman dan bertaqwa kepada Allah SWT. 
Keunggulan sumber daya manusia yang ingin dicapai pesantren adalah terwujudnya generasi muda yang menguasai tidak hanya aspek kognitif tetapi juga aspek afektif dan psikomotorik, tetapi sesuai dengan sifat distingtifnya sebagai sebuah lembaga pendidikan Islam yang mempunyai subkultur yang distingtif pula, pesantren jelas harus lebih mengorientasikan pengembangan para santrinya kearah penguasaan ilmu-ilmu agama Islam. Tetapi, memandang tantangan-tantangan yang dihadapi bangsa dan upaya penguasaan sainss dan tekhnologi untuk turut memelihara momentum pembangunan.

Untuk tujuan mulia di atas, peran pondok pesantren perlu ditingkatkan, tuntutan globalisasi tidak mungkin dihindari, maka salah satu langkah bijak adalah mempersiapkan pondok pesantren dalam persaingan pendidikan global agar tidak "ketinggalan kereta". Selain penguasaan atas sains dan teknologi yang dikemukakan sebelumnya, pondok pesantren juga perlu melakukan langkahlangkah strategis sebagai upaya pengembangan pendidikannya dalam menghadapi pendidikan global.

Kompetensi lulusan yang dikembangkan pondok pesantren dalam bidang akademik, meliputi: (1) Kemampuan untuk menguasai, menerapkan, dan mengembangkan ilmu dan teknologi untuk mencapai keunggulan sesuai dengan tuntutan pada tingkat nasional, regional maupun internasional, (2) Kemampuan untuk mandiri dan memiliki budaya kewirausahaan, memiliki kemampuan profesional dan integritas yang tinggi, yang memungkinkan mereka mampu bersinergi dan berkompetisi secara sehat dalam era informasi dan pasar bebas pada tingkat nasional, regional maupun internasional, (3) Kemampuan profesional yang tinggi untuk menerapkan dan mengembangkan ilmu, teknologi dan seni sesuai dengan tuntutan pembangunan nasional yang berkesinambungan, (4) Kemampuan untuk meningkatkan kualitas diri, wawasan dan sikap dalam upaya proses internalisasi nilai/kaidah ilmiah dalam menunaikan tugas-tugas keprofesionalannya, dan (5) Kemampuan menciptakan, menemukan dan mengembangkan berbagai ilmu dan teknologi. 
Selain itu, mencetak sarjana yang faham agama serta memahami teknologi, harus 'alim dalam ilmu fiqh, hukum, hadist dan qur'an. Selanjutnya mutu lulusan memiliki orientasi pada tujuan masa depan yang berbasis religious dan nasionalis, dan kultur pesantren, fokus pendidikan berlandaskan prinsip penyatuan pengetahuan, teori dan praktik. Strata pendidikan yang memenuhi keragaman tersebut distratifikasikan dalam program gelar. Keragaman program disusun dengan memperhatikan kebutuhan praktis. Memodifikasi lembaga pendidikan yang ideal membentuk generasi yang khairul ummah serta menjadikan konsep dalam pengembangan keilmuan yang sudah mulai disepakati dan diimplementasikan.

Sesuai dengan tujuan pembangunan Indonesia untuk mewujudkan manusia yang sejahtera lahir batin, maka penguasaan atas sains dan teknologi memerlukan perspektif etis dan panduan moral. Sebab, seperti juga terlihat dalam pengalaman negara-negara maju, kemajuan dan penguasaan atas sains dan teknologi yang berlangsung tanpa perspektif etis dan bimbingan moral akan menimbulkan berbagai konsekuensi dan dampak negatif yang membuat manusia makin jauh dari pusat eksistensial spiritualnya, maka autput pendidikan tinggi pesantren adalah menghasilkan output yang profesional dalam mengembangkan dan menyebarluaskan ilmu pengetahuan, teknologi dan seni yang bernafaskan Islam, mengupayakan penggunaannya untuk meningkatkan taraf kehidupan dan memperkaya kehidupan nasional yang memiliki karakteristik pokok: (a) berilmu, beramal, bertaqwa dan berakhlaqul karimah, (b) memiliki wawasan yang luas, dan (c) memiliki kematangan profesional.

\section{Membangun Networking dari lokal, regional dan global}

Pendidikan tinggi yang dikelola pondok pesantren memiliki multi misi yang diembannya, diantarannya dapat memberikan kontribusi yang fungsional dalam menjawab permasalahan yang dihadapi masyarakat dan pengembangan ilmu pengetahuan dan teknologi yang sesuai dengan kebutuhan pembangunan sekarang dan masa depan, sehingga pada akhirnya pendidikan pesantren 
tidak lagi dianggap sebagai manajemen sosial yang dikendalikan oleh subyek berwawasan sempit (pendekatan kekeluargaan), namun dikembangkan dalam pengelolaan pendidikan Islam dalam pola manajemen strategik, keputusan dan tindakan yang menghasilkan formulasi dan impelementasi rencana-rencana mencapai perubahan kearah kemajuan, bukan lagi penerapan manajemen insruksional yang kaku serta mengakumulasikan kerawanan masalah.

Melakukan kerja sama dengan berbagai institusi baik pemerintah maupun non pemerintah, bahkan dengan perguruan tinggi/lembaga lain, baik dari dalam maupun dari luar negeri. Kerja sama dilaksanakan dengan mengutamakan tugas pokok masingmasing lembaga pendidikan tinggi. Pengembangan kerjasama baik dalam maupun luar negeri, merupakan salah satu program pengembangan institusi dalam menjalin hubungan dengan pihak lain secara sistematis dan terbuka.

Strategi sebagai proses pengembangan dengan berorientasi pada jangkauan masa depan, dan ditetapkan sebagai keputusan yang bersifat mendasar dan prinsipil, agar memungkinkan organisasi berinteraksi secara efektif dalam mencapai tujuan organisasi (Nawawi, 2005:149-150). Dengan demikian dapat disimpulkan bahwa sumber-sumber strategi pengembangan pendidikan tinggi di pondok pesantren bersumber dari Al Qur'an, Al Hadits, Ijma dan Qiyas serta tradisi pesantren yang diturunkan dari para ulama' ahlussunnah wal jama'ah yang dilanjutkan oleh para kiyai-kiyai, selain itu tidak melupakan nilai-nilai nasionalisme dan kebermanfaatan terhadap masyarakat. Selanjutnya dapat diketahui bahwa sumber-sumber nilai pengembangan tersebut dijadikan lambang pondok pesantren sebagai bentuk komitmen dalam pengembangan pendidikan khususnya pendidikan tinggi.

Pimpinan pondok terus berupaya mendirikan lembaga-lembaga pendidikan, baik formal, informal maupun non formal dari tingkat dasar bahkan sampai perguruan tinggi. Pemberdayaan yang dilakukan oleh para pelopor, kiyai maupun pimpinan pondok pesantren mendapatkan banyak tantangan yang bersifat politis, kultural sosial maupun birokratik. Namun karena tanggung jawab 
serta dilaksanakan dengan ketulusan lembaga-lembaga pendidikan tersebut dapat tumbuh berkembang dengan menjalankan tradisi pesantren. Pendidikan tinggi yang dikelola pondok pesantren dituntut untuk merevitalisasi strateginya guna menjamin kesesuaian tututan lingkungan dan persaingan dengan kekuatan internal yang dimilikinya, mengingat ketidakmampuan suatu satuan pendidikan dalam merespons peluang dan ancaman eksternal akan mengakibatkan menurunnya daya saing dan atau terhambatnya pencapaian kinerja satuan pendidikan.

Kerjasama yang efektif dengan masyarakat, harus dilakukan oleh setiap komponen yang ada di pesantren secara langsung maupun tidka langsung. Secara fungsional semua komponen yang ada di pesantren ikut bertanggung jawab pada proses hubungan dengan masyarakat, namun dalam pelaksanaannya setiap komponen harus berperan sesuai dengan fungsi masing-masing. Pengembangan kerjasama baik dalam maupun luar negeri, merupakan salah satu program pengembangan institusi dalam menjalin hubungan dengan pihak lain secara sistematis dan terbuka. Kerjasama yang dimaksudkan mengarah pada upaya perbaikan akademik dan non akademik. Tujuan pelaksanaannya adalah.untuk menumbuhkan pemahaman masyarakat tentang visi, misi, program, dan keunggulan pendidikan tinggi yang dikelola pondok pesantren, menjalin komunikasi sosial dengan masyarakat profesi serta masyarakat umum, agar mampu mengangkat citra kelembagaan di masyarakat.

\section{Catatan Akhir}

Mutu lulusan yang diharapkan adalah memiliki kompetensi yang menggambarkan sosok utuh yang memiliki keahlian dan ketrampilan. Sosok utuh akan menggambarkan tanggungjawabnya dalam melaksanakan tugas. Kemampuan untuk menyelenggarakan serta menuntaskan pekerjaan. Untuk meningkatkan mutu lulusan pondok pesantren dan pengelola pendidikan tinggi melakukan standarisasi baku mutu kelayakan dan kinerja sebagai penyelenggara program pendidikan tinggi dari semua persyaratan dasar sebagai 
program sarjana yang berciri keislaman. Jaringan kerja sama; Pendidikan tinggi bukanlah suatu self sufficient institution. Lebih-lebih lagi di dalam dunia yang terbuka dewasa ini diperlukan kerja sama dalam bentuk kemitraan yang sejajar antara semua pendidikan tinggi. Antara PTN dengan PTN, antara PTS dengan PTS, dan antara PTS dengan PTN haruslah merupakan suatu jaringan kemitraan yang saling membantu.

Dengan kerja sama sumber-sumber yang tersedia akan saling melengkapi sehingga terjadi efisiensi di dalam sistem pendidikan tinggi nasional. Selain itu perlu juga dilengkapi dengan kerja sama dengan dunia industri lembaga-lembaga konsumen yang memerlukan tamatan - tamatan pendidikan tinggi.

\section{Daftar Pustaka}

David Sukardi Kodrat, Manajemen Strategi (membangun keunggulan bersaing era globalisasi di Indonesia berbasis kewirausahaan, (Yogyakarta: Graha Ilmu, 2009)

Garry Yulk. Kepemimpinan dalam Organisasi (Leadership in Organizations

3e.) (Jakarta: Prenhallindo, 1994)

Haryanto, Sosiologi Ekonomi. (Jakarta: Ar Ruzz Media 2011)

Hadari Nawawi. Managemen Strategik, (Yogyakarta, Gadjah Mada University Press, 2005.

Mastuhu, Memberdayakan Sistem Pendidikan Islam, Jakarta: Logos 1994)

Muslim Abdurrahman, Pendidikan Agama dalam Perspektif Pembangunan Bangsa, (1985). 